\title{
Geological Model of Latvia Developed at Riga Technical University (2010-2015)
}

\section{Latvijas hidroǵeoloǵiskā modeḷa izveidošana Rīgas Tehniskajā universitātē (2010.-2015. g.)}

\author{
Aivars Spalviňš \\ Rīgas Tehniskā universitāte, Latvija
}

\begin{abstract}
Kopsavilkums - Valsts pazemes ūdens resursu pārvaldībai tiek veidoti hidroǵeologiskie modeḷi (HM). Rīgas Tehniskā universitāte ir izstrādājusi divus Latvijas HM: REMO (Lielā Rīga) laika posmā no 1993. līdz 1996. gadam un LAMO1 (HM pirmā versija) no 2010. līdz 2012. gadam. REMO ietvēra Latvijas centrālo daḷu, tā plaknes režğa aproksimācijas solis bija $4000 \mathrm{~m}$. LAMO1 darbojas visā Latvijas teritorijā ar plaknes soli $500 \mathrm{~m}$. LAMO1 vispārina hidrog̀eoloğiskos un geoloğiskos datus, kurus apkopoja Latvijas Vides geologiijas un meteorologijas centrs. Lai uzlabotu HM rezultātu kvalitāti, laika posmā no 2012. līdz 2015. gadam notika LAMO1 papildināšana, kas īstenojās trīs secīgās versijās: LAMO2 (2013. g.), LAMO3 (2014. g.), LAMO4 (2015. g.). Šobrīd vispilnīgākā LAMO4 versija ir datu krātuve par ǵeoloǵisko slāṇu ğeometriju un filtrācijas īpašībām, pazemes ūdens līmeṇiem un plūsmām, pazemes un virszemes ūdens (upju, ezeru, jūras, atmosfēras nokrišṇu) mijiedarbību. LAMO4 jau tiek izmantots kā rīks dabas procesu pētīšanai Latvijas pazemes ūdens sistēmā.
\end{abstract}

Atslēgas vārdi - Geoloğiskie griezumi, hidrogrāfiskais tīkls, hidroǵeologiskais modelis, pazemes ūdens līmeṇi, pazemes ūdens plūsmu bilance.

\section{IEVADS}

Pasaules, tostarp Eiropas Savienības (ES), valstis pazemes ūdens resursu pārvaldībai veido hidroǵeologiskos model̦us (HM), kuros ar datormodelēšanas līdzekḷiem tiek iegūta plānošanai vajadzīgā informācija. ES valstis (arī Latvija) savu ūdens resursu apsaimniekošanai vadās no ES galvenās Ūdens Direktīvas [1], kura nosaka vienotus noteikumus ūdens resursu ilgtspējīgai izmantošanai.

Rīgas Tehniskā universitāte (RTU) ir izveidojusi divus Latvijas HM: REMO (Liela Rīga) [2] no 1993. līdz 1996. gadam un HM LAMO1 no 2010. līdz 2012. gadam. Laika posmā no 2013. līdz 2015. gadam LAMO1 tika būtiski papildināts ar nolūku palielināt tā rezultātu ticamību un kvalitāti. Abu HM autori ir RTU Vides modelēšanas centra (VMC) zinātnieki, tāpēc rakstā iekḷauta izziṇa par VMC vēsturi.

VMC izveidoja 1993. gadā uz 1960. gadā nodibinātās Elektromodelēšanas zinātniski pētnieciskās problēmu laboratorijas (EML) bāzes. Sākumā EML aktuālus ǵeofizikas un hidroǵeologijas uzdevumus risināja ar analogajām elektriskās modelēšanas metodēm un rīkiem. Vēlāk EML sāka attīstīt specializētās analogi cipariskās sistēmas un kḷuva par vadošu centru bijušajā PSRS pazemes ūdens un naftas resursu izmantošanas optimizācijā [3]. Visām EML izstrādnēm bija ne tikai teorētisks, bet arī praktisks lietojums.

VMC izmanto EML pieredzi hidroǵeologisko procesu modelēšanā un šobrīd strādā hidroinformātikas tematikā, t. i., hidroǵeologiijas un informātikas saskarsmē, izmantojot skaitlisko datormodelēšanu.

Laikā no 2010. līdz 2015. gadam ir īstenots visnozīmīgākais projekts EML un VMC 56 gadu ilgajā vēsturē - izveidots un pilnveidots Latvijas hidroǵeoloǵiskais modelis (LAMO). Šis modelis apkopo ǵeoloǵisko un hidroǵeoloǵisko informāciju, kura ir Latvijas Vides, ǵeologiijas un meteorologijas centra (LVG̣MC) rīcībā. LAMO digitālā formā dod datus par ǵeoloǵisko slānu ǵeometriju un filtrācijas īpašībām, pazemes ūdens līmeniem un plūsmām, pazemes un virszemes ūdens (jūras, upju, ezeru, atmosfēras nokrišnu) mijiedarbību. LAMO veido bāzi lokālu modeḷu izveidošanai un jau tiek izmantots kā līdzeklis dabas procesu pētǐšanai Latvijas pazemes ūdens sistēmā. Publikācija apraksta LAMO veidošanas un attīstības procesu.

\section{LAMO UN REMO SALĪDZINĀŠANA}

LAMO un REMO izvietojums ir redzams 1. attēlā. Abi modeḷi imitē hidroǵeoloǵiskos procesus tajā pazemes ūdens sistēmas daḷā, kuru Latvija izmanto dzeramā ūdens iegūšanai.

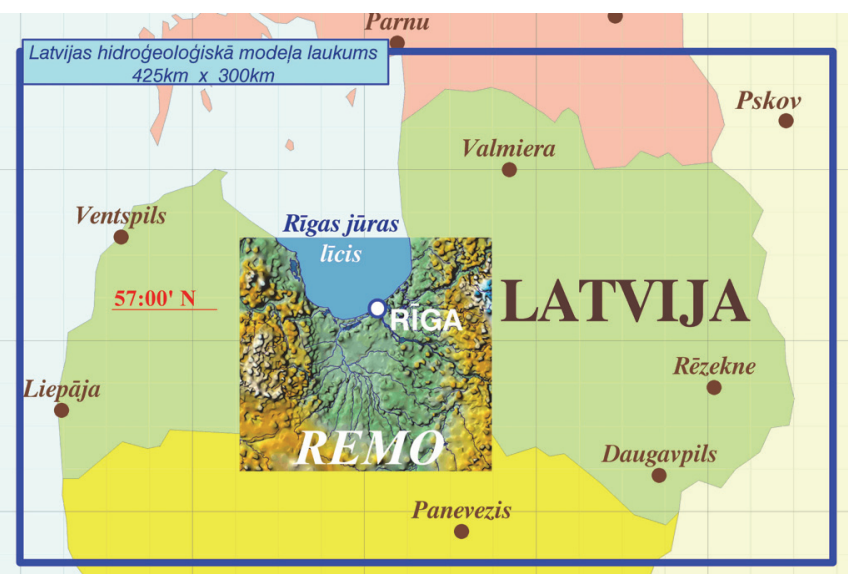

1. att. LAMO un REMO izvietojums. 
LAMO izmērs ir $475 \mathrm{~km} \times 300 \mathrm{~km}$. Šobrīd modela aktīiā daḷa ietver Latvijas sauszemes teritoriju un Rīgas jūras līci līdz Roṇu salai. Pagaidām modelī nedarbojas robežteritorijas ar kaiminvvalstīm. Šīs teritorijas var pievienot (aktivizēt), ja issteno pārrobežu projektus un kaimiņvalstis nodrošina ǵeologiskos un hidroǵeologískos datus robežteritorijām.

REMO VMC izveidoja 1993.-1996. g. Valsts ǵeoloǵijas dienesta (VG̣D) uzdevumā ar Dānijas un Grenlandes geoloǵijas dienesta atbalstu [2]. REMO izmērs bija $168 \mathrm{~km} \times 156 \mathrm{~km}$. REMO ietvēra Latvijas centrālo dalu, Lietuvas ziemel̦u pierobežu un ievērojamu Rīgas jūras līča daļu. Objektīvās grūtības ar vajadzīgo datu iegūšanu REMO Lietuvas pierobežai bija pamats prasībai, ka kaimiņvalstīm ir jānodrošina dati pierobežu teritoriju iekḷaušanai LAMO aktīvajā dạ̣ā.

REMO un LAMO1 (modela pirmā versija) galveno parametru salīdzinājumu dod I tabula:

- LAMO1 telpiskā režǵga bloku skaits ir 950 (14.25/0.015) reizes lielāks nekā REMO; režğa plaknes solis LAMO1 ir astoṇas reizes mazāks nekā REMO, t. i., LAMO1 nodrošina būtiski precīzāku ǵeolog̣iskās telpas īpašību ievērošanu modelī;

- LAMO1 darbojas licenzētas programmatūras vidē, bet REMO vajadzīiām VMC izstrādāja oriǵinālu programmatūru. REMO varēja sekmīgi lietot tikai VMC speciālisti, bet mēǵinājums REMO izmantot VG̣D nebija sekmīgs tieši oriǵinālās programmatūras dẹl;;

I TABULA

REMO UN LAMO1 GALVENO PARAMETRU SALİDZINĀJUMS

\begin{tabular}{|c|c|c|c|c|c|}
\hline \multirow{2}{*}{ Modelis } & \multirow{2}{*}{ Gads } & $\begin{array}{c}\text { Plaknes } \\
\text { solis, } \\
\mathrm{m}\end{array}$ & $\begin{array}{c}\text { Slāņu } \\
\text { skaits }\end{array}$ & $\begin{array}{c}\text { Režǵa } \\
\text { bloku } \\
\text { skaits, } \\
\times 10^{6}\end{array}$ & \\
\hline REMO & 1996 & 4000 & 9 & 0,015 & Orogrammatūrāinālā \\
\hline LAMO1 & 2012 & 500 & 25 & 14,25 & Licenzētā \\
\hline
\end{tabular}

Neskatoties uz REMO nepilnībām, VMC to sekmīgi izmantoja kā bāzi daudzu nozīmīgu hidroǵeoloǵisku problēmu risināšanai Latvijas centrālajai daḷai [3], [4], [5], [6], [7], [8], [9], [10]. VMC oriǵinālās metodes un rīki būtiski sekmēja reǵionāla tipa HM veidošanu Krievijā [11] un Lietuvā [12].

\section{LAMO1 IZVEIDOŠANA}

LAMO1 izveidoja (2010.-2012. g.), īstenojot ES līdzfinansētu ERAF projektu "Hidroǵeologiiskā modeḷa izveidošana Latvijas pazemes ūdens krājumu apsaimniekošanai un vides atveselošanai”.

LAMO1 tika īstenots, ievērojot VMC iespējas un LVG̣MC intereses [13], t. i., modelis: apraksta vidējos ilggadīgos Latvijas hidroǵeolog̣iskos apstākḷıs; izmanto LVG̣MC rīcībā esošos geoloğiskos un hidroǵeoloǵiskos datus par aktīvo pazemes ūdens zonu visai Latvijas teritorijai; lieto HM slānu vertikālo shematizāciju, kura atbilst LVG̣MC pienemtajai ǵeologískajai shēmai; ietver galvenos Latvijas hidrogrāfiskā tīkla elementus (upes, ezerus, jūru); izmanto režğa plaknes soli 500 metri.
LAMO1 tika iekḷutas 199 lielākās Latvijas upes un 67 ezeri. Nebija izveidoti upju iegrauzumi pamatiežos, un nebija izmantoti upju pazemes pieteču dati.

Modelī izmantota licenzēta programmatūra Groundwater Vistas (GV) [14]. GV tiek regulāri modernizēta (LAMO izmanto GV 6. versiju), tā ietver plašu specializēto programmu klāstu (MODFLOW [15], MODPATH [16], MT3D [17]), kuras pazemes ūdens procesu modelěšanai izmanto Eiropā un pasaulē.

HM izveidošanai VMC bija jāsagatavo šādas digitālās datnes: modeḷa slāṇu virsmu augstumi ( $z$ kartes); slāṇu filtrāaijas īpašības ( $k$ kartes); hidrogrāfiskā tīkla piesaistes datne; datne robežnoteikumiem modeḷa virsmai.

Par VMC oriǵinālajām metodēm un rīkiem, kuri tika izmantoti LAMO1 īstenošanai, informē raksts [18].

No 2. attēla var spriest, ka Latvijai ir lıti komplicēta geologiisko slāṇu uzbūve, jo tikai daži slāṇi eksistē visā valsts teritorijā.

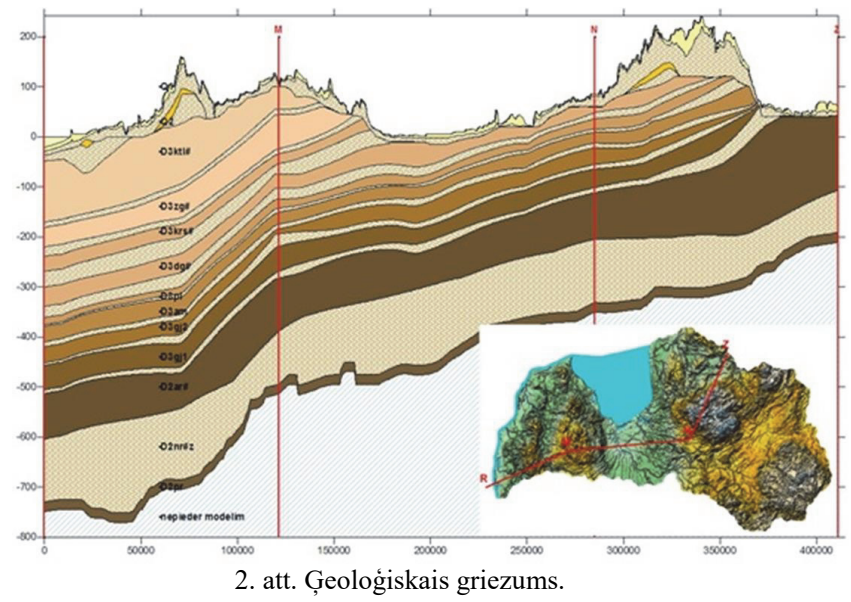

Šis apstāklis sarežğīja $z$ karšu iegūšanu [19]. Tikai izmantojot oriǵinālo VMC programmatūru ǵeoloğisko datu interpolācijai [20], izdevās iegūt augstas kvalitātes $z$ karšu kopumu. LAMO1 tika izmantotas vienkāršotas $k$ kartes ar fiksētām geologísko slāṇu filltrācijas koeficientu vērtībām.

Arī hidrogrāfiskā tīkla datne tika izveidota, izmantojot oriǵinālu VMC programmatūru [21].

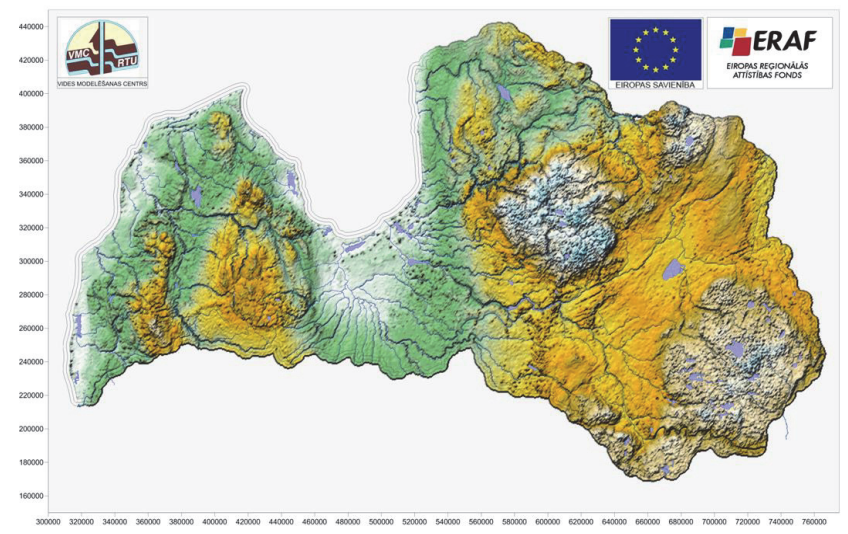

3. att. Digitālā reljefa virsma, kurā iekḷauti upes un ezeri. 
Robežnoteikumu datnē modeḷa ārējām virsmām vislielākā ietekme ir modeḷa augšējās virsmas reljefa kartei, kurā iekḷauti ezeri un upes kā zemes virsmas elementi (3. att.).

Šīs kartes izveidošanai izmantoti Latvijas Ģeotelpiskās informācijas aǵentūras dati.

Jau REMO tika konstatēts, ka, ja šo karti lieto kā robežnoteikumu, tad modelis pats izveido reālistisku infiltrācijas plūsmu. Šis apstāklis būtiski uzlabo HM rezultātu kvalitāti un ticamību [22]. Jau 2013. gada sākumā ar LAMO1 ieguva datus Igaunijas un Latvijas projektā par Gaujas-Koivas upju sateces baseinu [23]. Par pirmajiem ar LAMO1 iegūtajiem rezultātiem informēja raksts [24].

\section{LAMO PILNVEIDOŠANA}

Jau 2013. gadā tika iegūta nākošā pilnveidotā LAMO2 versija. Šobrīd eksistē četras modeḷa versijas un to galvenie dati apkopoti II tabulā.

II TABULA

LATVIJAS HIDROG̣EOLOG̣ISKĀ MODEḶA LAMO VERSIJAS

\begin{tabular}{|c|c|c|c|c|c|c|c|c|}
\hline \multirow[b]{2}{*}{ Versija } & \multirow[b]{2}{*}{ Gads } & \multicolumn{3}{|c|}{ Aproksimācijas režğis } & \multicolumn{3}{|c|}{ Model̦a upes } & \multirow{2}{*}{\begin{tabular}{|l} 
Ezeri \\
Skaits
\end{tabular}} \\
\hline & & $\begin{array}{c}\text { Plaknes } \\
\text { solis, } \\
\text { m }\end{array}$ & $\begin{array}{l}\text { Režǵa } \\
\text { plakņu } \\
\text { skaits }\end{array}$ & $\begin{array}{c}\text { Režǵa } \\
\text { šūnu } \\
\text { skaits, } \\
\times 10^{6}\end{array}$ & Skaits & $\begin{array}{c}\text { Ieleju } \\
\text { iegrauzumi }\end{array}$ & $\begin{array}{c}\text { Izmantoti } \\
\text { caurteces } \\
\text { dati }\end{array}$ & \\
\hline LAMO1 & 2012 & 500 & 25 & 14,25 & 199 & $\mathrm{Nav}$ & $\mathrm{Ne}$ & 67 \\
\hline LAMO2 & 2013 & 500 & 27 & 15,43 & 199 & $\mathrm{Ir}$ & $\mathrm{Ne}$ & 67 \\
\hline LAMO3 & 2014 & 500 & 27 & 15,43 & 469 & $\mathrm{Ir}$ & $\mathrm{Ne \overline {z }}$ & 127 \\
\hline LAMO4 & 2015 & 250 & 27 & 61,56 & 469 & Ir & Jā & 127 \\
\hline
\end{tabular}

Versijai LAMO2 īstenoti divi būtiski uzlabojumi:

- izveidoti upju iegrauzumi pamatiežos (4. att.);

- biezais D2ar geoloǵiskais slānis sadalīts ūdens horizontos D2brt un D2ar, kurus atdala sprostslānis D2arz (5. att.); modela slāṇu skaits pieauga no 25 uz 27.
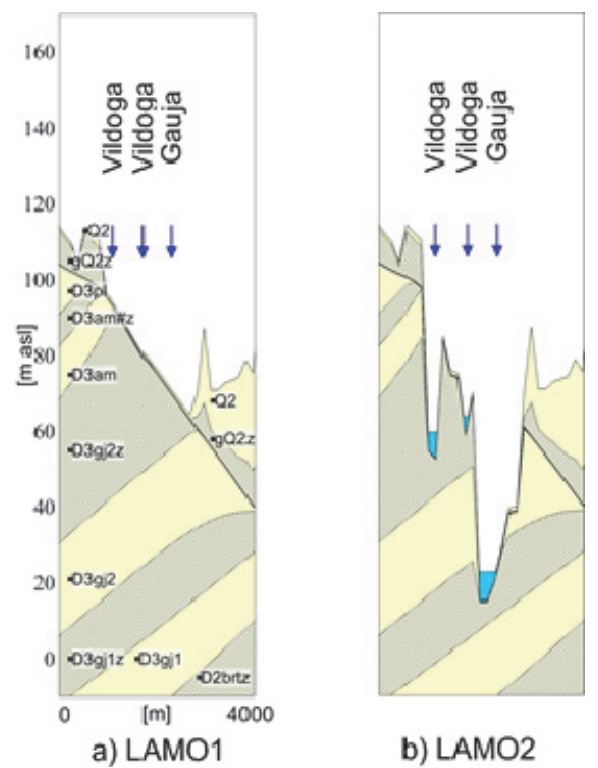

4. att. Gaujas un tās pieteces Vildogas ieleju iegrauzumi: a) LAMO1 - tikai Kvartāra slānī; b) LAMO2 - arī pamatiežos.

Izmantojot LAMO2 datus, VMC sagatavoja un iesniedza LVG̣MC pārskatus par visu četru Latvijas upju lielbaseinu
(Gaujas, Daugavas, Lielupes, Ventas) pazemes ūdensobjektu kartēšanu (6. att.) [25], [26], [27], [28]. Katrā pārskatā bija ietverti šādi dati:

- rakstiskā daḷa;

- $\quad \bar{u} d e n s$ līmeņu sadalījuma kartes ūdens horizontos;

- infiltrācijas plūsmu sadalījuma kartes sprostslāņos;

- pazemes ūdens plūsmu bilances tabulu un grafiskā formā;

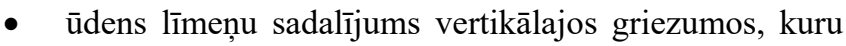
shēma skatāma 6. attēlā;

- pielikums, kurš bija iekḷauts visu upju lielbaseinu pārskatos. Tajā bija dota informācija par Latvijas teritoriju kopumā.

\begin{tabular}{|c|c|c|c|c|c|}
\hline $\begin{array}{c}\text { HM } \\
\text { slāņa Nr. }\end{array}$ & * & Slāņa nosaukums & $\begin{array}{l}\text { HM slāṇa } \\
\text { kods }\end{array}$ & $\begin{array}{l}\text { Laukums, } \\
\text { tūkst. } \mathrm{km}^{2}\end{array}$ & $\begin{array}{c}m_{\mathrm{vid}} \\
\mathrm{m}\end{array}$ \\
\hline 1 & & Reljefs & relh & 71,29 & 0,02 \\
\hline 2 & & Aerācijas zona & aer & 71,29 & 0,02 \\
\hline 3 & & $\begin{array}{l}\text { Bezspiediena } \\
\text { kvartārs }\end{array}$ & Q2 & 71,29 & 5,77 \\
\hline 4 & & Augšejā morēna & gQ2z & 71,29 & 22,20 \\
\hline 5 & & $\begin{array}{l}\text { Spiediena } \\
\text { kvartārs }\end{array}$ & Q1\# & 7,4 & 6,13 \\
\hline 6 & & Apakšējā morēna & gQ1\#z & 9,7 & 9,3 \\
\hline 7 & & Ketleru & D3ktl\# & 5,32 & 61,46 \\
\hline 8 & & Ketleru & D3ktlz & 5,79 & 10,52 \\
\hline 9 & & Zagares & D3zg\# & 7,43 & 42,65 \\
\hline 10 & & Akmenes & D3akz & 7,95 & 11,05 \\
\hline 11 & & Kursas & D3krs\# & 9,34 & 22,34 \\
\hline 12 & & Elejas & D3el\#z & 9,24 & 27,58 \\
\hline 13 & & Daugavas & D3dg\# & 32,14 & 30,37 \\
\hline 14 & & Salaspils & D3slp\#z & 35,78 & 12,67 \\
\hline 15 & & Plavinu & D3pl & 43,80 & 22,76 \\
\hline 16 & & Amatas & D3am\#z & 45,14 & 8,97 \\
\hline 17 & & Amatas & D3am & 46,21 & 21,91 \\
\hline 18 & & Upper Gauja & D3gj2z & 48,80 & 11,62 \\
\hline 19 & & Upper Gauja & D3gj2 & 50,92 & 26,34 \\
\hline 20 & & Lower Gauja & D3gj1z & 53,11 & 13,17 \\
\hline 21 & & Lower Gauja & D3gj1 & 56,13 & 31,55 \\
\hline 22 & & Burtnieku & D2brtz & 58,09 & 15,41 \\
\hline 23 & & Burtnieku & D2brt & 68,74 & 45,02 \\
\hline 24 & & Arikula & D2arz & 68,74 & 15,02 \\
\hline 25 & & Arikula & D2ar & 68,74 & 40,03 \\
\hline 26 & & Narva & D2nr\#z & 71,29 & 116,67 \\
\hline 27 & & Pernava & D2pr & 71,29 & 25,00 \\
\hline
\end{tabular}

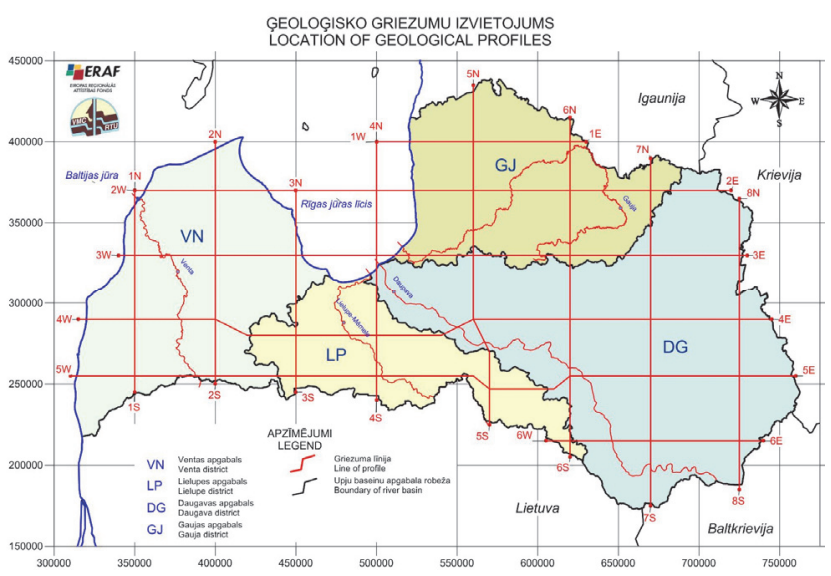

6. att. Latvijas upju lielbaseini un reǵionālo geologisko griezumu izvietojums 
Lai iegūtu vertikālo griezumu attēlus (arī pa upju viduslīnijām), VMC izveidoja speciālus programmatūras rīkus [29], [30], kuri nodrošināja pareizu ūdens līmeņu izolīniju vertikālo orientāciju ūdens horizontos (7. att.).

Pilnveidotās HM versijas LAMO3 un LAMO4 ir izstrādātas ar Valsts Pētījumu programmas EVIDEnT atbalstu. VMC šajā programmā īsteno uzdevumu "pilnveidot laba ūdens stāvokḷa ilgtspējīgai attīstībai nepieciešamo Latvijas hidroǵeoloǵisko modeli ar datiem un funkcijām, kas apraksta pazemes ūdeṇu mijiedarbību ar hidrogrāfisko tīklu (upes, ezeri)".

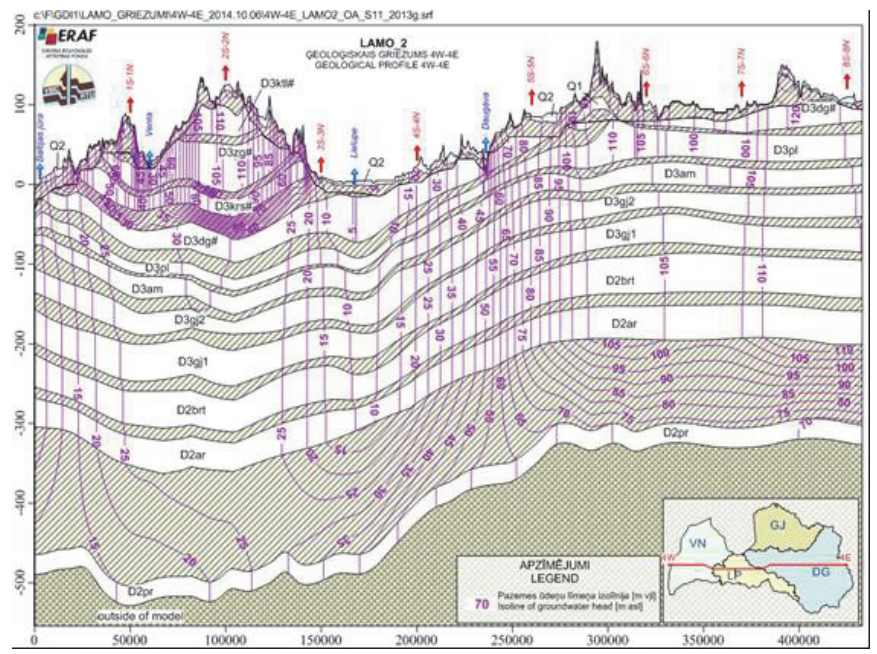

7. att. G̣eologiskais griezums 4W-4E LAMO2 versijā.

Pilnveidojumu būtība apskatīta rakstā [31]:

- jāpalielina hidrogrāfiskā tīkla blīvums, lai precīzāk modelētu upju un ezeru mijiedarbību ar pazemes ūdensobjektiem;

- lai novērstu HM upju un ezeru saskaršanos blīvajā hidrogrāfiskajā tīklā, režǵa plaknes solis jāsamazina no 500 uz 250 metriem;

- upju piesaiste HM jāveic, izmantojot datus par upju caurteces mērījumiem;

- jāuzlabo $k$ kartes pamatiežu ūdens horizontiem.

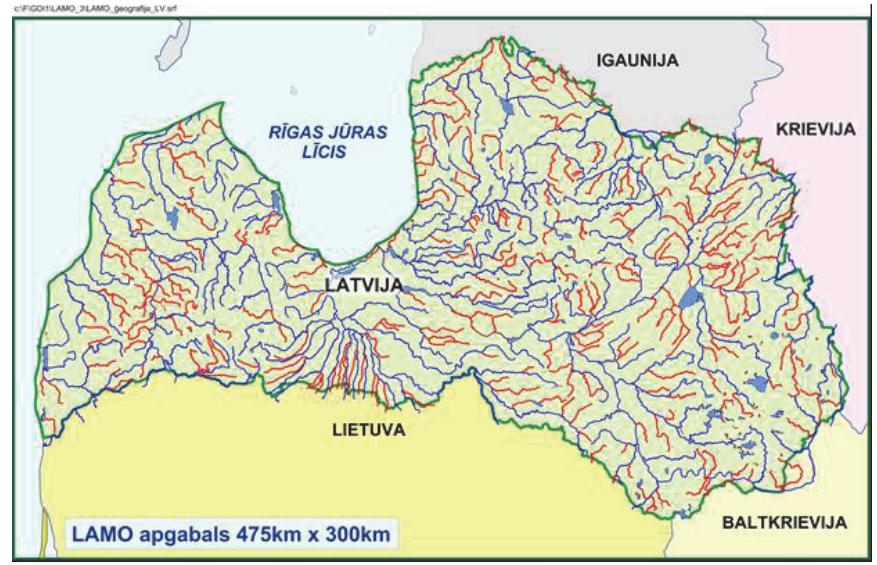

8. att. LAMO2 un LAMO3 hidrogrāiskie tîkli; LAMO2 - zilā krāsā; LAMO3 jaunie elementi - sarkanā krāsā.
Trešā (LAMO3) modeḷa versija tika izveidota 2014. gadā, kad būtiski tika palielināts hidrogrāfiskā tīkla blīvums (8. att., 2. tab.). Šis apstāklis jūtami ietekmēja modeḷa rezultātus, īpaši pazemes ūdens plūsmu bilances [31], [32]. Pārskatā par LAMO3 [33], kuru VMC iesniedza LVG̣MC, ǵeoloǵisko griezumu kartes izveidotas ne tikai ūdens līmeņu, bet arī infiltrācijas plūsmai (9. att.). Ūdens horizontu kartēs vienlaicīgi dots ūdens līmenu sadalījums un robusta infiltrācijas plūsmu karte (10. att.).

LAMO3 bija starpposms LAMO attīstībā, kurā pēc upju un ezeru skaita palielināšanas tika iegūti precīzāki dati par virszemes un pazemes ūdens objektu mijiedarbību un uzlabotas $k$ kartes pamatiežu ūdens horizontiem [33].

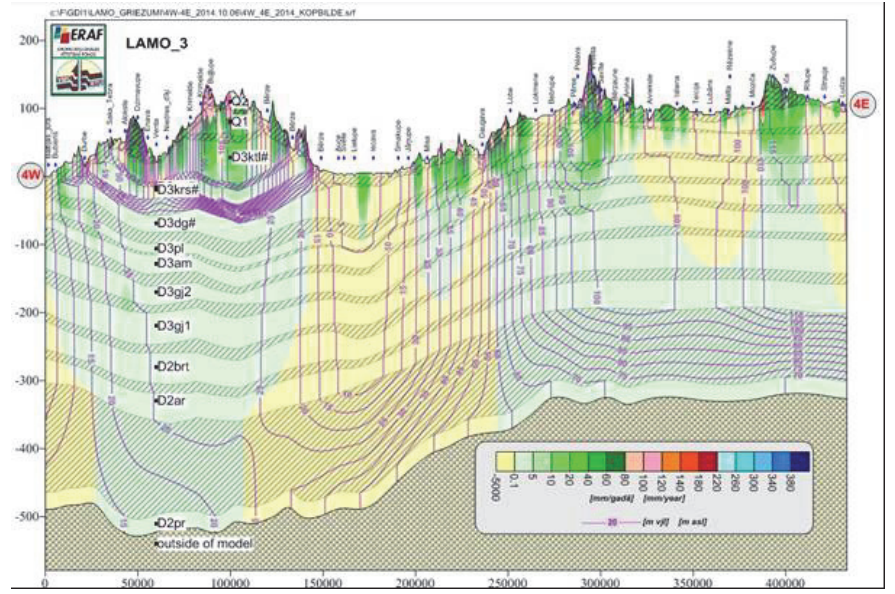

9. att. Ģeologiiskais griezums 4W-4E LAMO3 versijā.

Šobrīd pēdējā LAMO4 versija izveidota 2015. gadā pēc režǵa plaknes soḷa samazināšanas no 500 uz 250 metriem un upju pazemes pieteču kalibrācijas, ievērojot caurteces mērījumus upēs [34], [37]. Metodika upju piesaistei LAMO4 ir izklāstīta rakstā [34] un pārskatā [36]. Upju piesaistes lāgošanai izmantoti monogrāfijas [37] materiāli par Latvijas upju pazemes pieteces plūsmām un no upju caurteces mērījumiem. Dati par Latvijas pazemes ūdens plūsmu bilanci četriem lielbaseiniem, Latvijai kopumā, kvartāra un pamatiežu sistēmām ir skatāmi III tabulā [36].

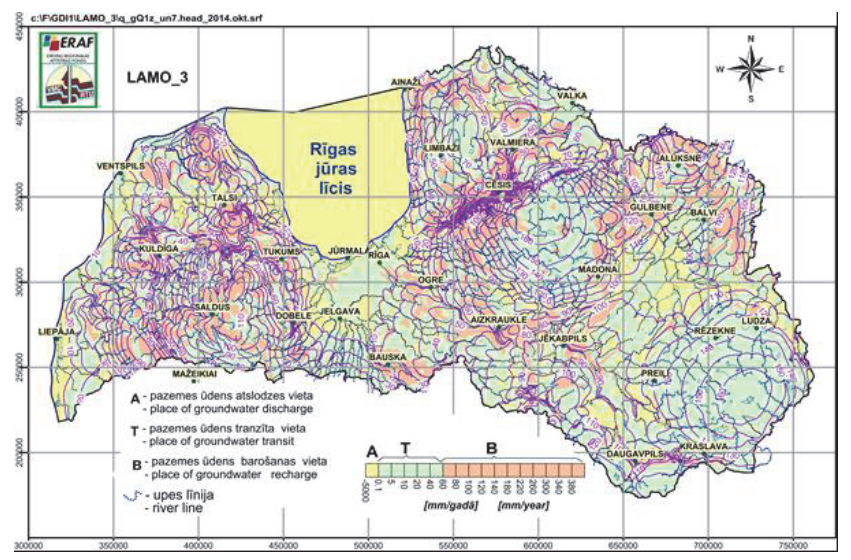

10. att. Plūsmu un ūdens līmeṇu sadalījums pamatiežu preQ horizontā. 
Tabulas pirmā kolonna atbilst atmosfēras nokrišnu daudzuma daḷai, kura nonāk pazemes ūdenī. Nākošās četras kolonnas rāda, kā atmosfēras nokrišn,i "baro" upes, ezerus, kā ùdens plūst caur baseina (valsts) robežu un kā pazemes ūdeni izmanto centralizētajai ūdens apgādei.

Salīdzinot ar LAMO2, LAMO4 versijai ir aptuveni dubultojušās aprēḳinātās atmosfēras nokrišnu, upju un ezeru plūsmas. Plūsmas caur robežu praktiski sakrīt abām versijām.

Ar LAMO4 iegūtie plūsmu bilanču dati atbilst vidējiem ilggadīgiem Latvijas apstākḷiem un būtiski koriǵē monogrāfijā [37] dotos upju pazemes pieteces plūsmu novērtējumus, kuri tika izmantoti LAMO1 un LAMO2 versijām.

III TABULA

LAMO4 PAZEMES ŪDENS PLŪSMU BILANCE (TŪKST. $\mathrm{M}^{3}$ / DNN) LIELBASEINIEM, KVARTĀRA UN PAMATIEŽU SISTĒMAI

\begin{tabular}{|c|c|c|c|c|c|c|}
\hline $\begin{array}{c}\text { Apgabala } \\
\text { nosaukums }\end{array}$ & $\begin{array}{c}q_{\text {toprezl }} \\
\text { pietece }\end{array}$ & $\begin{array}{c}q_{\text {rivers }} \\
\text { upes }\end{array}$ & $\begin{array}{c}q_{\text {lakes }} \\
\text { ezeri }\end{array}$ & $\begin{array}{c}q_{\text {border }} \\
\text { robeža }\end{array}$ & $\begin{array}{c}q_{\text {wells }} \\
\text { urbumi }\end{array}$ & $\begin{array}{c}\text { Laukums, } \\
\mathrm{km}^{2}\end{array}$ \\
\hline \multicolumn{7}{|c|}{ 1. Lielbaseini } \\
\hline Gauja & 3691 & -3471 & -86 & -116 & -18 & 13004,0 \\
\hline Daugava & 6247 & -5171 & -553 & -432 & -91 & 27063,6 \\
\hline Lielupe & 1100 & -1114 & -30 & 64 & -20 & 8857,2 \\
\hline Venta & 3183 & -2630 & -156 & -371 & -26 & 15629,9 \\
\hline Latvija & 14221 & -12386 & -825 & -855 & -155 & 64554,7 \\
\hline \multicolumn{7}{|c|}{2. Kvartāra sistēma } \\
\hline Gauja & 1977 & -1853 & -80 & -37 & -7 & 13004,0 \\
\hline Daugava & 4922 & -4538 & -369 & 34 & -49 & 27063,6 \\
\hline Lielupe & 977 & -955 & -29 & 7 & 0 & 8857,2 \\
\hline Venta & 2062 & -1764 & -126 & -172 & 0 & 15629,9 \\
\hline Latvija & 9938 & -9110 & -604 & -168 & -56 & 64554,7 \\
\hline & \multicolumn{7}{|c|}{3. Pamatiežu sistēma } \\
\hline Gauja & 1714 & -1618 & -6 & -79 & -11 & 13004,0 \\
\hline Daugava & 1325 & -633 & -184 & -466 & -42 & 27063,6 \\
\hline Lielupe & 123 & -159 & -1 & 57 & -20 & 8857,2 \\
\hline Venta & 1121 & -866 & -30 & -199 & -26 & 15629,9 \\
\hline Latvija & 4283 & -3276 & -221 & -687 & -99 & 64554,7 \\
\hline
\end{tabular}

Versijā LAMO1 un LAMO2 tika izmantotas vienkāršotas $k$ kartes, bet LAMO3 un LAMO4 lietotas daudz ticamākas $k$ kartes, kuras izveidotas, izmantojot urbumu atsūknēšanas datus [33], [35], [36], [38].

\section{LAMO4 KĀ RĪKS DABAS PROCESU PĒTİ̌̌ANAI LATVIJAS PAZEMES ŪDENS SISTĒMĀ}

Reǵionālie HM šobrīd pasaulē tiek izmantoti kā rīks ǵeoḳīmisko procesu pētīšanai pazemes ūdens sistēmās. Izcilus rezultātus sasnieguši Lietuviešu kolēgi [39], [40], kuriem VMC zinātnieki sniedza atbalstu reǵionāla HM izveidošanā Lietuvas dienvidaustrumu daḷai [12]. Šis HM pēc savām īpašībām un iespējām ir tuvs LAMO1 (izmantota GV sistēma, režǵa plaknes solis $500 \mathrm{~m}$ ).

Skaitliskie eksperimenti darbā [39] bija īstenoti HM $M O D F L O W$ vidē ar MODPATH sistēmas ūdens dalinu trasēšanas metodi [16]. Analizējot ūdens dalinu kustību, var iegūt datus par pazemes ūdens vecumu, izcelšanās vietu, ǵeoloǵiskajiem slāņiem, caur kuriem migrējis pazemes ūdens. Šo faktu kopums dod iespēju izskaidrot ǵeokīmiskos procesus un arī novērtēt pazemes ūdens piesārņošanas riska faktorus.

Disertācijā [40] ǵeoķīmisko procesu pētīšanai izmantota ne tikai $M O D P A T H$, bet arī MT3D sistēma, kura dod datus par pazemes ūden̄̄ izšḳ̄ịdušo vielu koncentrācijas maiṇu laikā un telpā.

VMC 2015. gadā ar LAMO4, izmantojot MODPATH, veica skaitlisku eksperimentu, lai noskaidrotu, no kurienes Iecavas upe saņem pazemes ūdeni [41]. Iecavas upei ūdens daļiņas tika ievietotas ar upi saistīto $\mathrm{HM}$ režğa šūnu centros (1027 dalininas).

Eksperimenta nolūks bija apstiprināt upju sateces apgabalu principa pareizību, t. i., "upes pazemes ūdens pieteces avots ir atmosfēras nokrišņi šajā apgabalā". Iecavas upe ir tipiska līdzenuma upe ar vienkāršu piesaisti ǵeologiskajai videi. Tomēr ar MODFLOW iegūtais rezultāts (11. att.) bija negaidīts šādu iemeslu dēḷ:

- ūdens dalinu $x y$ un $x z$ projekcijas veido škietami haotisku ainu;

- daudzu daḷiņu avoti kā atmosfēras nokrišṇi atrodas ḷti tālu (Vidzemes un Latgales augstiene) no Iecavas upes sateces apgabala;

- no dalinu trajektoriju $x z$ projekciju rakstura var secināt, ka tās uz Iecavas upi pārvietojas praktiski visos Latvijas aktīvās pazemes ūdens zonas geologiskajos slāṇos, kuri eksistē zem upes.

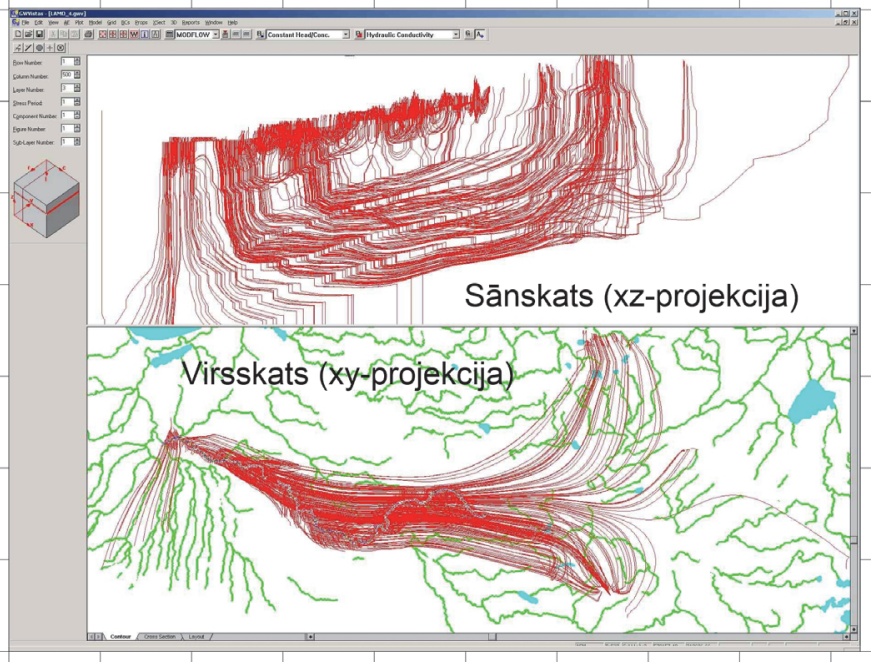

11. att. Traseru (1027) trajektoriju sānskats un virsskats (GV grafika).

Rakstā [41] veikta vispusīga šī skaitliskā eksperimenta rezultātu analīze, no kuras seko, ka Iecavas upei sateces apgabala princips ir apmierinoši izpildīts tikai tieši ar upi saistītajā kvartāra smilšu horizontā Q. Pazemes ūdens reǵionālo plūsmu darbības dēl šo principu nevar attiecināt uz dziḷākiem ūdens horizontiem.

Šiem secinājumiem ir tālejošas sekas, jo Direktīva [1] par pazemes ūdens objektu plānošanas pamatu izmanto sateces apgabalu principu, t. i., pārskatos [26], [27], [28], [29] izmantotais sateces apgabalu zonējums var būt kḷūdains, ja to attiecina uz ǵeoloǵiskajiem pamatiežiem (D3gj2, D3gj1, u. tml.), kurus Latvijā izmanto centralizētajai ūdens apgādei.

Rakstā [42] aprakstīts sarežǵîtāks pētījums, kura nolūks bija noskaidrot pazemes pieteces raksturu zemienes (Iecava) un augstienes (Malta) upju sateces apgabalam. 
Latvijas Universitātes zinātnieki 2015. gadā sekmīgi izmantoja LAMO4, lai pētītu atmosfêras nokrišnu stabilo izotopu migrāciju pazemes ūdenī [43].

Pagaidām VMC nepēta ǵeokīmiskos procesus, bet LAMO4 noteikti tiks izmantots arī šādiem nolūkiem. Šajos pētījumos izškiriroša nozīme būs $M T 3 D$ sistēmas izmantošanai.

Jāatzīmē, ka negaidītu un principiāli svarīgu rezultātu par upju sateces apgabalu bija iespējams iegūt tikai liela reǵionāla HM vidē (kā LAMO4).

\section{SECINĀJUMI}

İstenojot VPP EVIDEnT uzdevumu, ir izveidota LAMO4 versija, kurā izmantota precīzāka geologiskās telpas aproksimācija (režğa solis samazināts no 500 uz 250 metriem). Ticamākas pazemes ūdeņu un hidrogrāfiskā tīkla (upes, ezeri) mijiedarbības modelēšanai ir izmantoti upju caurteces mêrījumu dati.

LAMO4 pārbaude un koriǵēšana notika 2016. gadā, bet 2017. gadā VPP EVIDEnT iegūtā zinātība tiks izmantota, lai LAMO4 varētu izmantot Latvijā aktuālu hidroǵeoloǵisku problēmu risināšanā.

\section{LITERATŪRAS SARAKSTS}

[1] Eiropas Padomes direktīva 98/83EK (1998. gada 3. novembris) par dzeramā ūdens kvalitāti. (in Latvian).

[2] A. Spalviņ̌s, R. Janbickis, J. Šlangens, E. Gosk, I. Lāce, J. Atruškievičs, Z. Vỉksne, N. Levina, and J. Tolstovs, "Hidroǵeologiskais modelis „Lielā Rīga”. Karšu atlants,” Skaiț̦ošanas tehnika un robežproblēmas, issue 37, 102 p., 1996.

[3] A. Spalviņš, "Elektromodelēšanas zinātniski pētnieciskās laboratorijas vēsture (1960-2004)," Computer Science. Boundary Field Problems and Computer Simulation, vol. 21, issue 46, pp. 191-199, 2004. (in Latvian)

[4] A. Spalvins, E. Gosk, E. Grikevich, and J. Tolstov, Eds., "Modelling new well fields for providing Riga with drinking water," Boundary Field Problems and Computers, issue 38, 40 p. 1996.

[5] A. Spalvins, "Mass Transport Modelling in Groundwater Studies. Achievements of Latvian Scientists," in Environmental Contamination and Remediation Practices at Former and Present Military Bases, vol. 48 (NATO Science. Series 2: Environmental Security). F. Fonnum, B. Paukštys, B. A. Zeeb and K. J. Reimer Eds. Netherlands: Kluwer Academic Publishers, 1998, pp. 123-142. https://doi.org/10.1007/978-94-011-5304-1_11

[6] A. Spalvins, I. Semjonovs, E. Gosk, J. Gobins, and O. Aleksans, "Development of a Mathematical Model for Contamination Migration in the Area of the Sulphur-Tar Sludge Waste Pools in Incukalns, Latvia," in Proceedings of XXIX International Association of Hydrogeologists Congress on "Hydrogeology and Land Use Management", 610 September 1999, Bratislava, Slovak Republic, pp. 253-258, 1999.

[7] A. Spalvins, J. Slangens, R. Janbickis, and I. Lace, "Hydrogeological model of the Baltezers, Rembergi and Zakumuiza water supply complex, Latvia," in International Interdisciplinary Conference on Predictions for Hydrology, Ecology and Water Resources Management: Using Data and Models to Benefit Society, HydroPredict'2008, 15-18 September 2008, Prague, Czech Republic, pp. 1-9.

[8] A. Spalvins, J. Slangens, and I. Lace, "Modelling of groundwater regime changes that may be caused by building of transportation tunnel in Riga," Computer Science. Boundary Field Problems and Computer Simulation, vol. 5, issue 50, pp. 7-17, 2008. ISSN 1407-7493.

[9] A. Spalvins, J. Slangens, and I. Lace, "Modelling of remedy process for the hazardous liquid waste deposit area at the Jelgava town, Latvia," Proceedings of HydroEco $20092^{\text {nd }}$ International Multidisciplinary Conference on Hydrology and Ecologie, 20-23 April 2009, Wienna, Austria, 10 pages $\mathrm{CD}$.

[10] A. Spalvins, J. Slangens, I. Lace, and K. Krauklis, "Hydrogeological model of water supply system for the prospective factory of Coca-Cola company, Latvia," Computer Science. Boundary Field Problems and Computer Simulation, vol. 5, issue 51, pp. 21-28, 2009. ISSN 1407-7493.
[11] A. Spalvins, J. Slangens, R. Janbickis, I. Lace, L. Loukiantchikova, and E. Gosk, "The Noginsk District (Russia) Case as an Illustration of Novel Simulation Technologies Developed for Creating Hydrogeological Models," in Proceedings of the 10th International Conference on System-Modelling-Control, Zakopane, Poland, May 21-25, 2001. Lodz, 2001, vol. 2, pp. 225-230.

[12] A. Spalvins, J. Slangens, I. Lace, A. Stuopis, and A. Domasevicius, "Creating of regional hydrogeological model for south-east of Lithuania," Computer Science. Boundary Field Problems and Computer Simulation, vol. 5, issue 51, pp. 13-20, 2009. ISSN 1407-7493.

[13] A. Spalvins and U. Nulle, "Latvijas hidrogeologiskais modelis pazemes dzeramā ūdens krājumu pārvaldīšanai un atveseḷošanai," Computer Science. Boundary Field Problems and Computer Simulation, vol. 5, issue 53, pp. 7-13, 2011.

[14] Environmental Simulations, Inc. Groundwater Vistas. Version 6, Guide to using, 2011.

[15] W. Harbaugh, "MODFLOW-2005, U.S. Geological Survey Modular Ground-Water Model: the ground-water flow process," ch. 16, book 6, US Geological Survey Techniques and Methods 6-A16, USGS, Reston, VA.

[16] D. W. Pollok, “User's Guide for MODPATH/MODPATH-Plot, Version3. A particle tracking post-processing package for MODFLOW, the US Geological Survey finite-difference groundwater flow model," September 1994

[17] C. Zheng, "MT3D99 A modular three dimensional transport model for simulation of advection, dispersion and chemical reactions of contaminants in groundwater systems," USEPA report, USEPA, Washington, DC, 1999.

[18] A. Spalvins, J. Slangens, K. Krauklis, and I. Lace, "Methods and tools to be applied for creating of regional hydrogeological model of Latvia," in $25^{\text {th }}$ European Conference on Modelling and Simulation, June 7-10, 2011, Krakow, Poland, pp. 132-141. ISBN: 978-0-9564944-2-9. https://doi.org/10.7148/2011-0135-0141

[19] A. Spalvins, J. Slangens, I. Lace, K. Krauklis, O. Aleksans, and N. Levina, "Methods and software tools used to designate geometry for regional hydrogeological model of Latvia," Boundary Field Problems and Computer Simulation, issue 54, pp. 13-19, 2012. ISSN 1407-7493.

[20] A. Spalvins and J. Slangens, "Reliable data interpolation method for a hydrogeological model conductivity matrix," Sixth International Conference on "Calibration and Reliability in Groundwater Modeling. Credibility in Modelling." vol. 2, pp. 9-13, September 2007, Copenhagen, Denmark, pp. 137-142, 2007.

[21] K. Krauklis and J. Šlangens, "Special software used for implementing elements of hydrographical network into hydrogeological model of Latvia," Boundary Field Problems and Computer Simulation, vol. 53, pp. 24-28, 2014. ISSN 1407-7493. https://doi.org/10.7250/bfpcs.2014.004

[22] A. Spalvins, J. Slangens, I. Lace, and K. Krauklis, "Arrangement of boundary conditions for hydrogeological model of Latvia," Boundary Field Problems and Computer Simulation, issue 54, pp. 20-24, 2012. ISSN 1407-7493.

[23] Pazemes ūdensobjektu kartēšana Gaujas/Koivas upju baseinu apgabalā. Pārskats iepirkuma līgumam Nr. 62 starp Vides aizsardzības un reǵionālās attīstības ministriju un Rīgas Tehnisko universitāti, Rīga, Janvāris, 2013, 19 lpp., 25 kartes. [Online]. Available: www.emc.rtu.lv.

[24] A. Spalvins, J. Slangens, I. Lace, K. Krauklis, V. Skibelis, O. Aleksans, and N. Levina, "Hydrogeological model of Latvia, first results," Boundary Field Problems and Computer Simulation, issue 54, pp. 4-12, 2012. ISSN 1407-7493.

[25] A. Spalviņšs, J. Šlangens, I. Lāce, K. Krauklis, and O. Aleksāns, "Survey of the first results provided by hydrogeological model of Latvia," in 9-th International Conference Environmental Engineering, 22-23 May, 2014, Vilnius, Lithuania, Selected Papers, Vilnius Gediminas Technical University Press Technika, 2014, ISBN 978-609-457-690-4 CD, ISSN 2029-7092 online.

[26] Pazemes ūdensobjektu kartěšana Gaujas upju baseina apgabalā, Rīgas Tehniskā universitāte, Rīga, 2013, 12 lpp. 49 kartes, 6 tabulas (in Latvian) [Online]. Available: http://www.emc.rtu.lv/

[27] Pazemes ūdensobjektu kartēšana Daugavas upju baseina apgabalā, Rīgas Tehniskā universitāte, Rīga, 2013, 12 lpp. 52 kartes, 7 tabulas (in Latvian) [Online]. Available: http://www.emc.rtu.lv/.

[28] Pazemes ūdensobjektu kartēšana Lielupe upju baseina apgabalā, Rīgas Tehniskā universitāte, Rīga, 2013, 12 lpp. 55 kartes, 7 tabulas (in Latvian) [Online]. Available: http://www.emc.rtu.lv/. 
[29] Pazemes ūdensobjektu kartēšana Ventas upju baseina apgabalā, Rīgas Tehniskā universitāte, Rīga, 2013, 12 lpp. 57 kartes, 7 tabulas (in Latvian) [Online]. Available: http://www.emc.rtu.lv/.

[30] A. Spalviňš, J. Šlangens, O. Aleksāns, I. Lāce, and K. Krauklis, "Geological profiles as efficient means for expounding results provided by hydrogeological model of Latvia," in $14^{\text {th }}$ Geo Conference on Science and Technologies in Geology, Exploration and Mining (SGEM), Bulgaria, Albena, 17-26 June, 2014, pp. 401-408. ISBN 978-619-710508-7, ISSN 1314-2704. https://doi.org/10.5593/sgem2014B12

[31] A. Spalvins, J. Slangens, I. Lace, K. Krauklis, and O. Aleksans, "Efficient Methods Used to Create Hydrogeological Model of Latvia," International Rewiew on Modelling and Simulations, vol. 6, no. 5, pp. 1718-1726, October 2013. ISSN 1974-9821.

[32] A. Spalvins, J. Slangens, I. Lace, O. Aleksans, and K. Krauklis, "Hydrogeological Model of Latvia after increasing density of its hydrographical network," Boundary Field Problems and Computer Simulation, issue 55, pp. 12-24, 2014. ISSN 1407-7493. https://doi.org/10.7250/bfpcs.2014.003

[33] Latvijas hidroǵeoloǵiskā modela LAMO pilnveidošana, Pārskats līgumam 2014/15 starp LVG̣MC un RTU, Riga, 2014. g. novembris, vad. A. Spalviņš, teksts 10 lpp, attēli 14 lpp., tabulas 12. (in Latvian)

[34] A. Spalvins, J. Slangens, I. Lace, O. Aleksans, K. Krauklis, V. Skibelis, and I. Eglite, "The Novel Updates of the Hydrogeological Model of Latvia," Boundary Field Problems and Computer Simulation, vol. 54, pp. 23-34, 2015. https://doi.org/10.7250/bfpcs.2015.005

[35] A. Spalvins, I. Lace, and K. Krauklis, "Improved Methods for Obtaining Permeability Maps of Aquifers for Hydrogeological Model of Latvia," Boundary Field Problems and Computer Simulation, vol. 54, pp. 35-42, 2015. https://doi.org/10.7250/bfpcs.2015.006

[36] Latvijas hidroǵeoloǵiskā modeḷa LAMO pilnveidošanas starprezultāti, Pārskats līgumam 2014/15 starp LVG̣MC un RTU, Riga, 2015. g. novembris, vad. A. Spalviņš, teksts 30 lpp, pielikumi 53 lpp., (in Latvian). [Online]. Available: http://www.emc.rtu.lv/VPP/ATSK LVGMC 2015 teksts.pdf http://www.emc.rtu.lv/VPP/ATSK_LVGMC_2015_pielikumi.pdf.

[37] I. Dzilna, "Resources, composition and dynamics of groundwater for the middle part of the Baltic area," Zinātne, pp. 197, 1970. (in Russian).
[38] A. Spalvins, J. Slangens, I. Lace, O. Aleksans and K. Krauklis, "Improvement of hydrogeological models: a case study," International Review on Modelling and Simulations, vol. 8, no. 2, pp. 266-276, April 2015. https://doi.org/10.15866/iremos.v8i2.5868

[39] R. Mokrik, V. Juodkazis, A. Stuopis, and J. Mazeika, "Isotope geochemistry and modelling of the multi-aquifer system in the eastern part of Lithuania," Hydrogeology Journal, vol. 22, issue 4, pp. 925-941, 2014. https://doi.org/10.1007/s10040-014-1120-6

[40] A. Stuopis, "Formation and modelling assessment peculiarities of the quaternary aquifer system groundwater resources in the southeastern part of Lithuania," Summary of doctoral dissertation, Physical Sciences, geology (05 P) Vilnius, 2014, pp. 58.

[41] K. Krauklis, A. Spalvins, and J. Slangens, "The Hydrogeological Model of Latvia LAMO4 as a Tool for Investigating the Processes of Nature. Sources of Groundwater Inflow for the Iecava River," Boundary Field Problems and Computer Simulation, vol. 54, pp. 43-50, 2015. https://doi.org/10.7250/bfpcs.2015.007

[42] K. Krauklis, A. Spalviņš, and I. Eglīte, "Latvijas zemieņu un augstieņu upju īpašĩbu pētīšana ar Latvijas hidroǵeologiskā modeḷa palīdzību," Boundary Field Problems and Computer Simulation, vol. 55, pp. 28-33, 2016. https://doi.org/10.7250/bfpcs.2016.0074

[43] A. Kalvans, A. Babre, K. Popovs, A. Timuhins, and A. Spalvins, "Validating the regional hydrogeological models with stable isotope data in precipitation," in EGU General Assembly Conference Abstracts, Vienna, Austria, 17-22 April, 2016, pp. 12047.

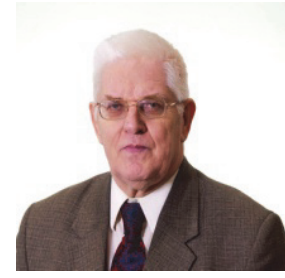

Aivars Spalviṇš was born in Latvia. In 1963, he graduated from Riga Polytechnical Institute (Riga Technical University since 1990) as a Computer Engineer. $\mathrm{He}$ is Head of the Environment Modelling Centre of RTU. His research interests include computer modeling of groundwater flows and migration of contaminants.

E-mail: aivars.spalvins@rtu.lv

Geological Model of Latvia Developed at Riga Technical University (2010-2015)

Aivars Spalvin̄š

Riga Technical University, Latvia

Hydrogeological models (HM) are developed in order to gain information that is needed for managing the protection and sustainable consumption of groundwater resources. The researchers of Riga Technical University (RTU) have developed two regional scales of HM of Latvia: in 1993-1996, REMO (Large Riga) and, in 2010-2012, LAMO1 (the first HM version). REMO covered the central part of Latvia and its plane approximation step was 4000 meters. LAMO1 encloses the ground territory of Latvia, the Gulf of Riga, and border areas with neighbouring countries (Estonia, Lithuania, Russian Federation, Belorussia). The HM plane step is 500 metres. Presently, the neighbouring areas of $\mathrm{HM}$ are not active. In the case of a transboundary projects the neighbouring country must provide hydrogeological data necessary to activate its neighbouring area. LAMO1 generalizes geological and hydrogeological data that have been accumulated by the Latvian Environment, Geology and Meteorology Centre (LEGMC). LAMO runs into the environment of licensed software Groundwater Vistas that is being used worldwide for modelling groundwater processes. In 2012-2015, LAMO1 was considerably updated, in order to improve the quality of results provided by HM. The LAMO2 version (2013) accounted for deep river valleys cutting the primary strata; the thick Devonian D2ar aquifer was replaced by the two aquifers and the aquitard that separated them; due to this innovation, the number of the HM planes increased from 25 to 27 . In 2014, the LAMO3 version was obtained by increasing the density of the HM hydrogeological network (number of rivers and lakes, increased, accordingly, from 199 to 469 and from 67 to 127). For the current LAMO4 version, the plane step was reduced from 500 to 250 meters; the groundwater inflow for rivers was calibrated by accounting for information obtained from measurements of river flows. For LAMO1 and LAMO2, the permeability of primary aquifers (k-maps) was modelled by using a constant permeability value for an aquifer. In LAMO3 and LAMO4, more realistic k-maps were obtained by accounting for pumping data of wells.

Presently, the latest LAMO4 version is being used by LEGMC and RTU specialists as the source of information on the geometry and permeability of geological strata, on distributions of groundwater heads and flows, on interaction between groundwater and surface water bodies (sea, lakes, rivers, precipitation). LAMO4 has been used by RTU researchers as a tool for investigating nature processes of the groundwater system of Latvia. The first results were quite unexpected, because it was found that the river watershed basin concept could not be used for the deepest strata of the basin.

The research on LAMO3 and LAMO4 is supported by the Latvian state research program EVIDEnT.

Keywords - hydrogeological model, hydrographical network, groundwater heads, groundwater flow balance, geological section. 